\title{
PENGARUH TANGGUNGJAWAB PELAKSANAAN FUNGSI BISNIS DAN FUNGSI SOSIAL TERHADAP JUMLAH DANA PIHAK KETIGA BANK UMUM SYARIAH DI INDONESIA (Periode Tahun 2010-2015)'
}

\author{
Nafisah Ruhana \\ Mahasiswa Progam Studi S1 Ekonomi Islam - Fakultas ekonomi dan Bisnis - Universitas \\ Airlangga \\ Email: nafisah.ruhana-12@feb.unair.ac.id \\ Noven Suprayogi \\ Departemen Ekonomi Syariah - Fakultas Ekonomi dan Bisnis - Universitas Airlangga \\ Email: noven.suprayogi@febis.unair.ac.id
}

\begin{abstract}
:
This study aims to find out the simultaneous and partial impact of Good Corporate Governance index and Islamic social reporting index as an assessment of the responsibility for the implementation of business functions and social functions towards total third-party funds on Islamic Banks in Indonesia during 2010-2015. This study use quantitative approach, and the sampling technique is purposive sampling. The analysis technique used is the panel data regression. The type and sources of data used are secondary data. The population in this study are Islamic Banks in Indonesia.

The results of this study showed that index of good corporate governance partially have no significant effect on the number of third-party funds while index of Islamic Social Reporting partially have significant effect on the amount of funding third parties. Simultaneously index of Good Corporate Governance and Islamic Social Reporting have significant effect on the number of third-party funds Islamic banks.
\end{abstract}

\section{Keywords: Good Corporate Governance, Islamic Social Reporting, Third-parties Fund,}

\section{PENDAHULUAN}

Bank syariah lahir sebagai lembaga kevangan yang melaksanakan kegiatannya berdasarkan pada prinsip Islam. Antonio (2001:201) menjelaskan bahwa bank syariah memiliki beberapa fungsi yaitu, sebagai manajer investasi, investor, sebagai penyedia jasa kevangan, dan pengemban jasa sosial. Fungsi bank syariah sebagai manajer investasi, investor, dan penyedia jasa keuangan erat kaitannya dengan fungsi bisnis Sedangkan, fungsi bank syariah sebagai pengemban jasa sosial adalah fungsi sosial bank syariah.

Sebagai bank yang melaksanakan kegiatannya berdasarkan pada prinsip Islam Bank Umum Syariah memiliki tanggungjawab melaksanakan fungsi bisnisnya dengan baik. Disebutkan dalam Al-Quran sebagai sumber utama hukum Islam yaitu dalam surat Al-Mudatsir ayat 38.

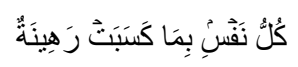

Kullu nafsin bimā kasabat rahīnatun

Artinya: "Tiap-tiap diri bertanggungjawab atas apa yang telah diperbuatnya". (Q.S. 74:38, Departemen Agama Rl, 201 1:576)

Katsir (2005:343) menjelaskan surat Almudatsir ayat 38 bahwa setiap orang bergantung dengan amalnya pada hari akhir nanti. Demikianlah yang dikatakan ibnu abbas. Kelak di hari kiamat, setiap orang akan mempertanggungjawabkan semua amal perbuatan yang telah dikerjakannya sewahtu hidup di dunia.

${ }^{[1]}$ Jurnal ini merupakan bagian dari Skripsi Nafisah Ruhana NIM 041211432120 yang diuji pada tanggal 16 Februari 2016 
Ruhana, et al/Jurnal Ekonomi Syariah Teori dan Terapan Vol. 5 No. 4 April 2018: 264-278; PENGARUH TANGGUNGJAWAB PELAKSANAAN FUNGSI BISNIS DAN FUNGSI SOSIAL TERHADAP JUMLAH DANA PIHAK KETIGA BANK UMUM SYARIAH DI INDONESIA (PERIODE TAHUN 20102015)

Setiap orang baik bertindak sebagai individu maupun sebagai sebuah entitas akan dimintai petanggungjawaban atas amalan yang dilakukannya di dunia pada hari pembalasan nanti.

Fungsi bisnis dijalankan oleh bank umum syariah dengan tujuan untuk memperoleh keuntungan. Boone (2002:8) menjelaskan bahwa bisnis terdiri dari seluruh aktivitas yang bertujuan untuk mendapatkan keuntungan dengan menyediakan barang dan jasa yang dibutuhkan bagi sistem perekonomian, sebagian bisnis memproduksi barang berwujud sedangkan yang lain memberikan jasa. Penjelasan diatas memberikan arti bahwa fungsi bisnis bank umum syariah merupakan segala aktivitas bank syariah yang bertujuan untuk memperoleh keuntungan melalui kegiatan menghimpun dan menyalurkan dana serta memberikan jasa keuangan lainnya dengan akad sesuai syariah agar tercapai kesejahteraan masyarakat.

Bank umum syariah membutuhkan manajemen yang baik dalam menjalankan fungsi bisnisnya. Manajemen sebagai suatu metode pengelolaan yang baik dan benar, untuk menghindari kesalahan dan kekeliruan dan menegakkan kebenaran (Rivai, 2010:479). Konsep manajemen berkaitan dengan memaksimumkan stakeholder value (Rivai, 2010:474). Sehingga, secara tidak langsung dalam jangka panjang, adanya manajemen yang baik dengan tujuan memaksimalkan stakeholder value, juga dapat memberikan nilai positif bagi citra perusahaan serta kelangsungan perusahaan itu sendiri. Pentingnya sebuah manajemen yang baik dalam kaitannya menjaga kelangsungan sebuah perusahaan dibuktikan dengan adanya Peraturan Bank Indonesia Nomor 11/ 33/ PBI/2009 Tentang Pelaksanaan Good Corporate Governance bagi Bank Umum Syariah dan Unit Usaha Syariah dan Peraturan Otoritas Jasa Keuangan No. 8/POJK.03/2014 tentang Penilaian Tingkat Kesehatan Bank Umum Syariah dan Unit Usaha Syariah yang mengharuskan bank umum syariah untuk menerapkan Good Corporate Governance (GCG).

Good Corporate Governance adalah bagaimana seharusnya perusahaan melakukan pengelola dengan baik sehingga dapat meningkatkan kepercayaan para pemangku kepentingannya. Perusahaan yang dikelola dengan baik akan dapat memunculkan keyakinan dari pelanggan dan kepercayaan dari pasar (Ramadhani, 2009:2). Good corporate governance memuat prinsip transparansi, akuntabilitas, responsibilitas, independensi, dan kewajaran dan kesetaraan yang dibutuhkan oleh stakeholdernya untuk menilai tingkat tanggung jawab dalam pelaksanaan fungsi bisnis. Peraturan OJK no. 8 tahun 2014 menyebutkan bahwa 
Ruhana, et al/Jurnal Ekonomi Syariah Teori dan Terapan Vol. 5 No. 4 April 2018: 264-278; PENGARUH TANGGUNGJAWAB PELAKSANAAN FUNGSI BISNIS DAN FUNGSI SOSIAL TERHADAP JUMLAH DANA PIHAK KETIGA BANK UMUM SYARIAH DI INDONESIA (PERIODE TAHUN 20102015)

penilaian terhadap faktor Good Corporate Governance merupakan penilaian terhadap manajemen Bank Umum Syariah untuk menilai tingkat Good Corporate Governance yang telah dilakukan perusahaan. Kriteria indikator atau indeks yang berisikan item-item untuk menilai tingkat Good Corporate Governance yang telah dilakukan perusahaan diatur dalam Surat Edaran OJK no 10 tahun 2014.

Undang-Undang Republik Indonesia Nomor 21 tahun 2008 tentang perbankan syariah menyebutkan bahwa selain menjalankan fungsi menghimpun dan menyalurkan dana masyarakat, bank syariah dapat menjalankan fungsi sosial dalam bentuk lembaga baitul mal yaitu menerima dana dari zakat, infaq, sedekah, hibah, atau dana sosial lain dan menyalurkannya kepada pengelola zakat. Pelaksanaan fungsi sosial oleh bank umum syariah menjadi salah satu kriteria dalam mengevaluasi performance bank, karena disamping memperhatikan keuntungannya bank syariah juga harus memperhatikan kepentingan masyarakat (Rivai, 2010:210).

Penilaian tanggungjawab pelaksanaan fungsi sosial bank umum syariah salah satunya menggunakan indeks Islamic Social Reporting (ISR).

Islamic Social Reporting merupakan alternatif pengukuran kinerja sosial bagi entitas syariah yang pada pengukuran kinerja sosial sistem konvensional sebelumnya tidak terdapat prinsip syariah. Haniffa (2002:128) berpendapat bahwa pada pelaporan kinerja sosial sistem konvensional hanya mempertimbangkan aspek material dan moral dan kurang dalam menggunakan pertimbangan aspek spiritual. Aspek spiritual dibutuhkan dalam pelaporan tanggung jawab sosial entitas syariah karena untuk membantu dalam pemenuhan kebutuhan spiritual para pembuat keputusan Muslim. Indeks Islamic Social Reporting didalamnya mencakup penilaian terhadap keuangan dan investasi, produk, karyawan, masyarakat, dan lingkungan yang pada setiap itemnya mengandung prinsipprinsip Islami.

Sebagai lembaga intermediasi, perbankan harus memiliki kinerja yang baik karena dengan kinerja yang baik, bank akan lebih mudah mendapatkan kepercayaan dari para nasabah lagent of trust). Dengan adanya kepercayaan dari masyarakat, bank akan mampu menghimpun dana dari masyarakat secara maksimal yang kemudian akan disalurkan dalam bentuk kredit sehingga bank dapat menjalankan fungsi utamanya sebagai penyalur dana. Ismail (2011:40) mengatakan bahwa masyarakat memercayai bank syariah dan membutuhkan keberadaan bank syariah sebagai tempat yang aman untuk menyimpan dana. 
Ruhana, et al/Jurnal Ekonomi Syariah Teori dan Terapan Vol. 5 No. 4 April 2018: 264-278; PENGARUH TANGGUNGJAWAB PELAKSANAAN FUNGSI BISNIS DAN FUNGSI SOSIAL TERHADAP JUMLAH DANA PIHAK KETIGA BANK UMUM SYARIAH DI INDONESIA (PERIODE TAHUN 20102015)

Penilaian indeks GCG dan ISR dapat menjadi sarana bagi stakeholder untuk melihat tanggungjawab pelaksanaan fungsi bisnis dan fungsi sosial oleh bank umum syariah. Pengungkapan informasi mengenai GCG dan kinerja sosial oleh perusahaan merupakan tindakan pemberian sinyal positif oleh perusahaan kepada seluruh stakeholder yang mengindikasikan bahwa perusahaan terkait telah mengelola perusahaan dengan baik dan telah melakukan kinerja sosial untuk kesejahteraan masyarakat. Berdasarkan teori sinyal informasi tersebut merupakan sinyal positif yang diharapkan dapat direspon positif pula oleh masyarakat termasuk masyarakat yang kemudian akan meletakkan dananya pada bank bersangkutan.

\section{Pengungkapan Good Corporate} Governance dan Islamic Social Reporting oleh perusahaan dapat dilihat sebagai suatu sinyal dari manajemen kepada pihak luar bahwa perusahaan telah dikelola sebagai mana mestinya (sinyal positif). Sinyal positif yaitu ketika Bank Umum Syariah melakukan tata kelola perusahaan yang baik diukur menggunakan Indeks Good Corporate Governance dan melaksanakan kinerja sosial yang diukur menggunakan Indeks Islamic Social Reporting diharapkan dapat direspon masyarakat dan tertarik untuk menempatkan dananya pada bank. Perusahaan yang memiliki citra baik dimata masyarakat akan lebih diminati. Perusahaan dengan citra baik tidak hanya mementingkan laba tetapi juga sosial dan lingkungan sekitarnya (Venanzi dan Fidanza, 2006 dalam Friori et. al, 2007:6). Para investor akan lebih tertarik menginvestasikan modalnya apabila terdapat Social Reporting pada suatu perusahaan (Prastuti dan Budiasih, 2015:116).

Berdasarkan latar belakang masalah di atas, maka rumusan masalah pada penelitian ini adalah sebagai berikut:

1. Apakah indeks Good Corporate Governance berpengaruh terhadap jumlah dana pihak ketiga pada bank unum syariah di Indonesia?

2. Apakah indeks Islamic Social Reporting berpengaruh terhadap jumlah dana pihak ketiga pada bank umum syariah di Indonesia?

3. Apakah indeks Good Corporate Governance dan indeks Islamic Social Reporting secara simultan berpengaruh terhadap jumlah dana pihak ketiga pada bank umum syariah di Indonesia?

Adapun tujuan dari penelitian ini adalah untuk mengetahui pengaruh indeks Good Corporate Governance dan indeks Islamic Social Reporting secara parsial dan simultan terhadap jumlah dana pihak ketiga pada Bank Umum Syariah di Indonesia.

\section{TINJAUAN PUSTAKA}


Ruhana, et al/Jurnal Ekonomi Syariah Teori dan Terapan Vol. 5 No. 4 April 2018: 264-278; PENGARUH TANGGUNGJAWAB PELAKSANAAN FUNGSI BISNIS DAN FUNGSI SOSIAL TERHADAP JUMLAH DANA PIHAK KETIGA BANK UMUM SYARIAH DI INDONESIA (PERIODE TAHUN 20102015)

Bank Umum Syariah (BUS) adalah bank yang melaksanakan kegiatan usaha sesuai dengan prinsip syariah dan melaksanakan kegiatan lalu lintas pembayaran. Bank umum syariah adalah bank syariah yang berdiri sendiri sesuai dengan akta pendiriannya, bukan merupakan bagian dari bank konvensional sehingga laporan yang diterbitkan adalah milik sendiri (Ismail, 2011:51-52). Beberapa contoh BUS antara Iain Bank Syariah Mandiri, Bank Muamalat Indonesia, Bank Mega Syariah, Bank Syariah Bukopin, Bank BCA Syariah, dan Bank BRI Syariah. Berdasarkan Peraturan Bank Indonesia nomor 11/ 33 /PBI/2009 Tentang Pelaksanaan Good Corporate Governance bagi Bank Umum Syariah dan Unit Usaha Syariah, bahwa bank umum syariah wajib melaksanakan GCG dan menyusun laporan pelaksanaan GCG.

Menurut Pedoman Good Corporate Governance yang dikeluarkan oleh Komite Nasional Kebijakan Governance (KNKG, 2006), Good Corporate Governance (GCG) adalah salah satu pilar dari sistem ekonomi pasar yang berkaitan erat dengan kepercayaan baik terhadap perusahaan yang melaksanakannya maupun terhadap iklim usaha di suatu negara mendorong terciptanya persaingan yang sehat dan iklim usaha yang kondusif.
Emirzon (2006:94) mendefinisikan good governance sebagai penekanan pada bagaimana mengatur hubungan antara semua pihak yang berkepentingan dengan perusahaan yang diwujudkan dalam satu sistem pengendalian perusahaan. Sutedi (2001:1) Corporate Governance dapat didefinisikan sebagai suatu proses dan struktur yang digunakan oleh organ perusahaan (pemegang saham/ pemilik modal, komisaris/ dewan pengawas dan direksi) untuk meningkatkan keberhasilan usaha dan akuntabilitas perusahaan guna mewujudkan nilai pemegang saham dalam jangka panjang dengan tetap memperhatikan kepentingan stakeholder lainnya, berlandaskan peraturan perundang-undangan dan nilai-nilai etika.

Prinsip-prinsip

Corporate Governance agar tercipta praktik Good Corporate Governance berdasarkan pedoman umum Good Corporate Governance yang dikeluarkan oleh Komite Nasional Kebijakan Govenance (KNKG) adalah Transparansi, Akuntabilitas, Responsibilitas, Independensi, Kewajaran dan kesetaraan. Prinsip-prinsip tersebut dapat menciptakan konsep tata kelola perusahaan yang baik.

Islamic social reporting adalah standar pelaporan pertanggungjawaban sosial bagi perusahaan-perusahaan yang berbasis syariah sebagai bentuk akuntabilitas dan transparansi tidak hanya 
Ruhana, et al/Jurnal Ekonomi Syariah Teori dan Terapan Vol. 5 No. 4 April 2018: 264-278; PENGARUH TANGGUNGJAWAB PELAKSANAAN FUNGSI BISNIS DAN FUNGSI SOSIAL TERHADAP JUMLAH DANA PIHAK KETIGA BANK UMUM SYARIAH DI INDONESIA (PERIODE TAHUN 20102015)

kepada masyarakat tetapi juga untuk membantu perusahaan dalam melakukan pemenuhan kewajiban terhadap Allah SWT (Haniffa, 2002). Menurut Haniffa (2002) terdapat banyak keterbatasan dalam pelaporan sosial konvensional, sehingga ia membuat kerangka konseptual pelaporan sosial yang berdasarkan ketentuan syariah. Indeks ISR terdiri dari item item pengungkapan pelaporan kinerja sosial institusi bisnis syariah. Indeks ISR dari penelitian Othman dan Thani (2010) dengan enam tema pengungkapan yaitu: pendanaan dan investasi, produk dan jasa, karyawan, masyarakat, lingkungan, dan tata kelola perusahaan.

Good Corporate Governance yang merupakan suatu bentuk pertanggungjawaban dalam mengelola perusahaan memiliki peran penting dalam rangka pemeliharaan kepercayaan oleh Bank Umum Syariah kepada para stakeholdernya. Penerapan prinsip corporate governance diharapkan dapat meningkatkan kualitas laporan keuangan, yang pada akhirnya meningkatkan kepercayaan pemakai laporan keuangan (Sulistyanto, 2003)

Dana pihak ketiga merupakan dana nasabah dalam bentuk simpanan. Simpanan menurut Undang-undang No.10/1998 pasal 1 ayat 5 adalah dana yang dipercayakan oleh masyarakat kepada bank berdasarkan perjanjian penyimpanan dana dalam bentuk giro, deposito, sertifikat deposito, tabungan dan atau bentuk lainnya yang dipersamakan dengan itu. Dengan demikian kepercayaan oleh para stakeholder terutama oleh nasabah kepada Bank Umum Syariah penting untuk dipelihara karena dana pihak ketiga adalah wujud eksistensi kepercayaan nasabah pada Bank Umum Syariah yang bersangkutan.

Pengungkapan informasi mengenai Good Corporate Governance dan Islamic social reporting oleh perusahaan merupakan tindakan pemberian sinyal positif oleh perusahaan kepada seluruh stakeholder yaitu sinyal bahwa perusahaan terkait telah mengelola perusahaan dengan baik dan telah melakukan aktivitas sosial. Pemberian informasi dilakukan perusahaan sebagai bentuk pemeliharaan kepercayaan terhadap stakeholdernya dan diiharapkan bagi nasabah untuk menyimpan dananya pada Bank Umum Syariah. Sinyal positif dari perusahaan diharapkan akan mendapatkan respon positif dari pasar, yang kemudian dapat memberikan keuntungan kompetitif bagi perusahaan serta memberikan nilai yang tinggi bagi perusahaan (Widarjo, 2011:7)

Hipotesis

H1 : Terdapat pengaruh indeks Good Corporate Governance terhadap dana 
Ruhana, et al/Jurnal Ekonomi Syariah Teori dan Terapan Vol. 5 No. 4 April 2018: 264-278; PENGARUH TANGGUNGJAWAB PELAKSANAAN FUNGSI BISNIS DAN FUNGSI SOSIAL TERHADAP JUMLAH DANA PIHAK KETIGA BANK UMUM SYARIAH DI INDONESIA (PERIODE TAHUN 20102015)

pihak ketiga pada bank umum syariah di Indonesia.

H2 : Terdapat pengaruh indeks Islamic Social Reporting terhadap dana pihak ketiga pada bank umum syariah di Indonesia.

H3 : Terdapat pengaruh indeks Good Corporate Governance dan Islamic Social Reporting secara simultan terhadap dana pihak ketiga pada bank umum syariah di Indonesia

\section{Model Analisis}

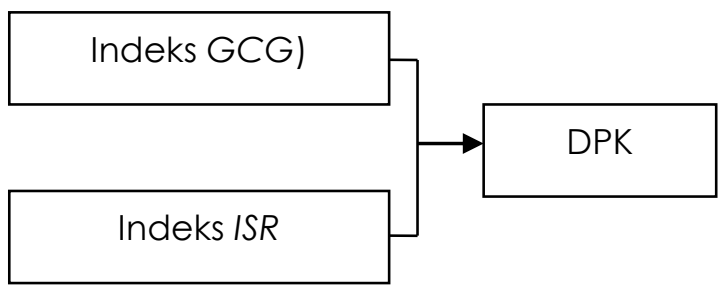

Sumber : Data diolah

\section{Gambar 2.1}

Pengaruh indeks Good Corporate Governance dan Islamic Social Reporting terhadap jumlah dana pihak ketiga

\section{METODOLOGI PENELITIAN}

\section{Pendekatan Penelitian}

Pendekatan penelitian yang digunakan dalam penelitian ini adalah pendekatan kuantitatif. Penelitian dengan menggunakan pendekatan kuantitatif adalah penelitian yang menitikberatkan pada pengujian hipotesis, data yang digunakan harus terukur, dan akan menghasilkan kasimpulan yang dapat digeneralisasikan. (Anshori dan Iswati, 2009:155)

\section{Identifikasi Variabel}

\begin{abstract}
Variabel Independen dalam penelitian ini adalah indeks Good Corporate Governance (X1), dan indeks Islamic Social Reporting (X2), serta variabel dependen adalah jumlah dana pihak ketiga $(Y)$.
\end{abstract}

\section{Definisi Operasional}

1. Indeks Good Corporate Governance (X1)

Indeks GCG merupakan sebuah kriteria/indikator yang berisikan item-item untuk menilai tingkat Good Corporate Governance yang telah dilakukan perusahaan. Indeks GCG yang digunakan dalam penelitian ini adalah nilai komposit hasil self assessment pelaksanaan Good Corporate Governance berdasarkan Surat Edaran Otoritas Jasa Kevangan No. 10/SEOJK.03/2014 perihal Penilaian Tingkat Kesehatan Bank Umum Syariah dan Unit Usaha Syariah yang dilakukan oleh masing-masing bank yang terdapat dalam laporan pelaksanaan GCG.

2. Indeks Islamic Social Reporting (X2)

Indeks ISR merupakan sebuah checklist yang berisikan item-item untuk menilai tingkat Islamic Social Reporting sebuah perusahaan yang berbasis syariah. Penilaian pengungkapan ISR berupa nilai (skor) yang diperoleh dari analisis tingkat pengungkapan Islamic Social Reporting (ISR). Penilaian indeks ISR dilakukan dengan menggunakan scoring dari nilai 0-1, dimana : 
Ruhana, et al/Jurnal Ekonomi Syariah Teori dan Terapan Vol. 5 No. 4 April 2018: 264-278; PENGARUH TANGGUNGJAWAB PELAKSANAAN FUNGSI BISNIS DAN FUNGSI SOSIAL TERHADAP JUMLAH DANA PIHAK KETIGA BANK UMUM SYARIAH DI INDONESIA (PERIODE TAHUN 20102015)

a. Nilai 0 jika tidak ada pengungkapan terkait item,

b. Nilai 1 jika ada pengungkapan terkait item.

Apabila seluruh item telah diungkapkan maka nilai maksimal yang dapat dicapai adalah sebesar 43. Othman, et al (2009) menyatakan, bahwa perhitungan indeks pengungkapan ISR dirumuskan sebagai berikut:

$I S R=$ Jumlah item yang diungkapkan perusahaan/Jumlah item yang diharapkan diungkapkan perusahaan $\mathrm{X}$ $100 \%$

Nilai ISR diperoleh dari annual report pada Bank Umum Syariah mulai tahun 2010 hingga 2014 dan skala pengukuran nilai ISR menggunakan skala rasio.

3. Dana Pihak Ketiga ( $Y$ )

Dana pihak ketiga merupakan seluruh dana yang dihimpun oleh Bank Umum Syariah melalui berbagai macam produk penghimpunan dana antara lain yaitu, giro wadiah, tabungan mudharabah, deposito mudharabah. Jumlah dana pihak ketiga yang digunakan dalam penelitian ini didapat dari laporan tahunan masing-masing bank.

\section{Jenis dan Sumber Data}

Jenis data yang digunakan dalam penelitian ini adalah data sekunder. Sumber data sampel penelitian ini didapat dari laporan pelaksanaan GCG dan laporan tahunan (annual report) periode 2010-2015 yang diterbitkan oleh masing-masing Bank Umum Syariah (BUS) melalui website resmi masing-masing BUS.

Data yang digunakan adalah data panel, yaitu gabungan data time series dan data cross section selama enam tahun yaitu mulai dari tahun 2010 sampai dengan tahun 2015 dipilih karena cukup menggambarkan kondisi terkini. Data yang digunakan dalam penelitian ini bersumber dari laporan tahunan (annual report) dan laporan pelaksanaan GCG masing-masing bank umum syariah yang diterbitkan melalui website masing-masing bank serta dari sumber lain bila diperlukan.

\section{Populasi dan Sampel}

Populasi yang digunakan dalam penelitian ini adalah seluruh Bank Umum Syariah di Indonesia. Pemilihan populasi tersebut karena Bank Umum Syariah berdiri secara mandiri sehingga memiliki kewenangan penuh untuk memutuskan pelaporan yang akan dilakukan. Berdasarkan data yang tersedia, teknik sampel yang digunakan dalam penelitian ini adalah purposive sampling. Adapun kriteria sampel yang akan digunakan dalam penelitian ini adalah sebagai berikut:

1. Bank Umum Syariah (BUS) yang beroperasi di Indonesia sejak tahun 2010 atau sebelumnya hingga tahun 2015. 
Ruhana, et al/Jurnal Ekonomi Syariah Teori dan Terapan Vol. 5 No. 4 April 2018: 264-278; PENGARUH TANGGUNGJAWAB PELAKSANAAN FUNGSI BISNIS DAN FUNGSI SOSIAL TERHADAP JUMLAH DANA PIHAK KETIGA BANK UMUM SYARIAH DI INDONESIA (PERIODE TAHUN 20102015)

2. Bank Umum Syariah (BUS) yang telah mempublikasikan laporan GCG dan laporan tahunan periode 2010-2015 secara konsisten di website resmi masingmasing bank.

\section{Teknik Analisis}

Penelitian ini merupakan penelitian kuantitatif. Teknik analisis yang digunakan dalam penelitian ini adalah regresi data panel. Proses perhitungan dalam penelitian ini menggunakan progam Eviews. Teknik analisis data dalam penelitian ini memanfaatkan data yang didapatkan dari penggabungan antara data cross section (beberapa BUS tertentu) dengan data time series (lingkup waktu selama beberapa tahun tertentu) atau disebut dengan data panel. Dalam regresi data panel pertama-tama diilakukan uji chow untuk menentukan model PLS atau FEM yang digunakan. Apabila FEM diterima selanjutnya melakukan uji hausman untuk menentukan model FEM atau REM yang digunakan. Setelah menentukan model yang tepat, uji berikutnya adalah uji t dan uji $F$, lalu koefisien determinasi. Uji $\dagger$ digunakan untuk menguji pengaruh secara parsial variabel independen terhadap variabel dependen, sedangkan uji $F$ digunakan untuk menguji pengaruh secara simultan variabel independen terhadap variabel dependen.

IV. HASIL DAN PEMBAHASAN
Setelah dilakukan uji chow untuk menentukan model PLS atau FEM yang tepat digunakan. Berikut hasil uji chow:

Tabel 2

Hasil Uji F (Chow Test)

Sumber: Output Eviews 9

Berdasarkan tabel 2 di atas, diperoleh nilai probabilitas (Cross-section F) sebesar 0,0000 lebih kecil dari a $(0,05)$ sehingga $\mathrm{Hl}$ diterima, dan dapat disimpulkan bahwa Fixed Effect Model (FEM) lebih sesuai dibandingkan dengan Pooled Least Square (PLS)/ Commond Effect Model (CEM).Selanjutnya dilakukan Uji Hausman untuk mengetahui apakah teknik regresi data panel dengan fixed effect lebih dari model regresi data panel random effect.

Hipotesis Uji Hausman adalah :

Ho : Random Effect Model (REM)

$\mathrm{H}_{1} \quad$ : Fixed Effect Model (FEM)

Tabel 3

Hasil Pengujian Hausman Test

\begin{tabular}{|c|c|c|}
\hline Test Summary & $\begin{array}{l}\text { Chi-Sq. } \\
\text { Statistic }\end{array}$ & $\begin{array}{l}\text { i-Sq. } \\
\text { d.f. Prob. }\end{array}$ \\
\hline $\begin{array}{l}\text { Cross-section } \\
\text { random }\end{array}$ & $\begin{array}{r}1.49623 \\
4\end{array}$ & 20.4733 \\
\hline
\end{tabular}


Ruhana, et al/Jurnal Ekonomi Syariah Teori dan Terapan Vol. 5 No. 4 April 2018: 264-278; PENGARUH TANGGUNGJAWAB PELAKSANAAN FUNGSI BISNIS DAN FUNGSI SOSIAL TERHADAP JUMLAH DANA PIHAK KETIGA BANK UMUM SYARIAH DI INDONESIA (PERIODE TAHUN 20102015)

\section{Sumber: Output Eviews 9}

Berdasarkan tabel 3 di atas, diperoleh nilai probabilitas (Cross-section random) sebesar 0.4733 lebih besar dari a $(0,05)$ sehingga $\mathrm{HI}$ diterima, dan dapat disimpulkan bahwa Random Effect Model (REM) lebih sesuai dibandingkan dengan Fixed Effect Model (FEM)

Berdasarkan hasil estimasi REM didapat bentuk persamaan liniernya sebagai berikut:

$D P K=24.93942+0.168065$ GCG + 8.358195 ISR

Selanjutnya dilakukan uji $†$ (uji parsial) dan uji $F$ (uji simultan) dan koefisien determinasi (R-square). Uji $\dagger$ digunakan untuk menguji pengaruh variabel independen secara parsial terhadap variabel dependen.

\section{Tabel 4}

Hasil Uji $\dagger$

\begin{tabular}{|c|r|c|c|c|}
\hline $\begin{array}{c}\text { Variabl } \\
\mathrm{e}\end{array}$ & $\begin{array}{r}\text { Coefficie } \\
\text { nt }\end{array}$ & Std. Error & t-Statistic & Prob. \\
\hline $\mathrm{C}$ & 24.93942 & 0.638421 & 39.06421 & 0.0000 \\
\hline & & & & \\
GCG? & 0.168065 & 0.106636 & 1.576073 & 0.1231 \\
\hline & & & & \\
ISR? & 8.358195 & 0.878996 & 9.508799 & 0.0000 \\
\hline
\end{tabular}

Berdasarkan taber 4 di atas, maka Variabel Indeks GCG memiliki tingkat probabilitas (t-statistic) sebesar 0.1231 yang lebih besar dari a $(0,05)$, sehingga H_Ol diterima. Kesimpulan yang dapat diperoleh adalah Indeks GCG berpengaruh tidak signifikan terhadap jumlah DPK. Dan Variabel Indeks ISR memiliki tingkat probabilitas (t-statistic) sebesar 0.0000 yang lebih kecil dari a $(0,05)$, sehingga H_02 ditolak. Kesimpulan yang dapat diperoleh adalah Indeks ISR berpengaruh signifikan positif terhadap jumlah DPK karena koefisien ISR menunjukkan nilai yang positif

Uji $F$ digunakan untuk menguji pengaruh variabel independen secara simultan terhadap variabel dependen

Tabel 5

Hasil Uji F dan R-Square

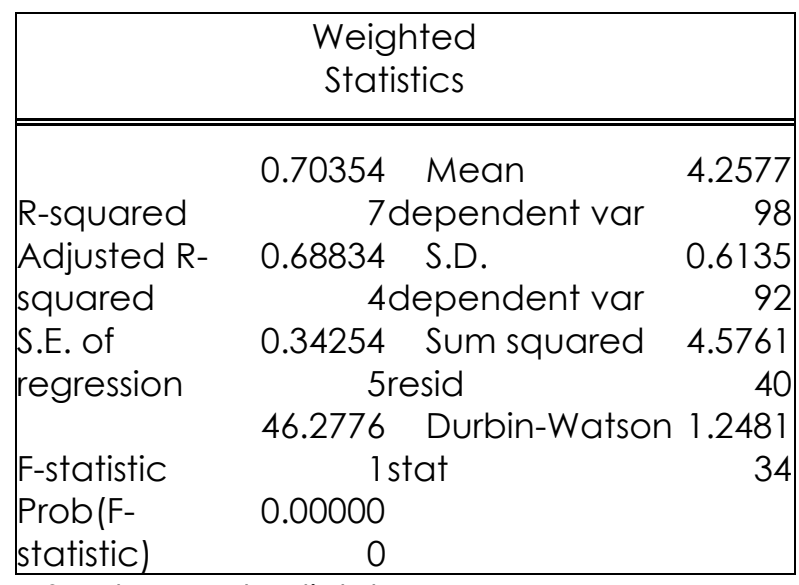

Sumber: Data diolah

Berdasarkan tabel 5 di atas, dapat dilihat tingkat probabilitas (F-statistic) sebesar 0,000000 lebih kecil dari a $(0,05)$, sehingga H_O ditolak dan dapat disimpulkan bahwa Indeks ISR dan GCG secara simultan berpengaruh signifikan terhadap jumlah DPK

Berdasarkan tabel 5 di atas, dapat dilihat bahwa nilai Adjusted R-squared sebesar 0.688344. hal ini menunjukkan bahwa variabel Indeks GCG dan ISR dapat menjelaskan variabel jumlah DPK 
Ruhana, et al/Jurnal Ekonomi Syariah Teori dan Terapan Vol. 5 No. 4 April 2018: 264-278; PENGARUH TANGGUNGJAWAB PELAKSANAAN FUNGSI BISNIS DAN FUNGSI SOSIAL TERHADAP JUMLAH DANA PIHAK KETIGA BANK UMUM SYARIAH DI INDONESIA (PERIODE TAHUN 20102015)

sebesar 68,83\%, sedangkan sisanya dijelaskan oleh variabel-variabel lain diluar model atau diluar variabel-variabel yang diteliti.

\section{Pengaruh Indeks Good Corporate Governance terhadap Jumlah Dana Pihak Ketiga}

Pengaruh Indeks GCG terhadap jumlah dana pihak ketiga secara parsial dapat dilihat dari hasil tingkat probabilitas (t-statistic). Berdasarkan hasil pengolahan regresi data panel diketahui bahwa tingkat probabilitas (t-statistic) sebesar 0.1231 yang lebih besar dari a (0.05), sehingga H_01 diterima dan dapat disimpulkan bahwa Indeks GCG tidak berpengaruh signifikan terhadap jumlah dana pihak ketiga.

Penerapan Good Corporate Governance oleh perusahaan dapat dilihat sebagai suatu sinyal yang menandakan bahwa perusahaan memiliki sistem tata kelola yang baik dalam menjalankan bisnisnya. Apabila hal tersebut sudah tercipta maka perusahaan dapat membina hubungan yang baik dengan para stakeholder sebagai suatu respon akibat sinyal positif yang diberikan oleh bank. Hubungan yang baik tersebut akan menimbulkan kepercayaan yang tinggi dari para stakeholder termasuk masyarakat yang kemudian akan menaruh dananya pada bank umum syariah. Mahaputra (2011:15) mengatakan bahwa Good Corporate Governance dapat meningkatkan citra perusahaan dimata publik sehingga dapat lebih mudah menarik investor.

Hasil penelitian ini menunjukkan bahwa indeks Good Corporate Governance tidak berpengaruh signifikan terhadap jumlah dana pihak ketiga. Indeks GCG yang tidak berpengaruh signifikan terhadap jumlah dana pihak ketiga tersebut disebabkan oleh bank yang masing-masing secara mandiri melakukan penilaian self assessment. Bank Umum Syariah dalam membuat laporan baik itu laporan tahunan maupun laporan pelaksanaan GCG akan berusaha sebisa mungkin untuk membuat laporan sesuai dengan peraturan yang telah di tentukan regulator yaitu berdasarkan Surat Edaran Otoritas Jasa Keuangan No. 10 tahun 2014. Penilaian self assessment pelaksanaan GCG sendiri dilakukan terhadap sebelas faktor penilaian pelaksanaan GCG, yaitu: pelaksanaan tugas dan tanggung jawab dewan komisaris; pelaksanaan tugas dan tanggung jawab direksi; kelengkapan dan pelaksanaan tugas komite; pelaksanaan tugas dan tanggung jawab Dewan Pengawas Syariah; pelaksanaan prinsip syariah dana kegiatan penghimpunan dana dan penyaluran dana serta pelayanan jasa; penanganan benturan kepentingan; penerapan fungsi kepatuhan bank; penerapan fungsi audit intern; penerapan fungsi audit ekstern; 
Ruhana, et al/Jurnal Ekonomi Syariah Teori dan Terapan Vol. 5 No. 4 April 2018: 264-278; PENGARUH TANGGUNGJAWAB PELAKSANAAN FUNGSI BISNIS DAN FUNGSI SOSIAL TERHADAP JUMLAH DANA PIHAK KETIGA BANK UMUM SYARIAH DI INDONESIA (PERIODE TAHUN 20102015)

batas maksimum penyaluran dana; transparansi kondisi keuangan dan non keuangan, laporan peaksanaan GCG dan pelaporan internal. Ketentuan faktorfaktor penilaian penilaian pelaksanaan GCG tersebut terdapat poin-poin yang lebih rinci lagi, contoh pada faktor pelaksanaan tugas dan tanggung jawab dewan komisaris terdapat ketentuan bahwa jumlah anggota Dewan Komisaris paling kurang tiga orang dan paling banyak sama sengan jumlah anggota direksi, paling kurang 1 orang anggota Dewan Komisaris berdomisili di Indonesia dan lain sebagainya. Ketentuan yang rinci dan jelas terdapat dalam peraturan menjadi acuan bagi bank umum syariah dalam pelaksanaan Good Corporate Governance.

Ketentuan yang jelas dan menjadi acuan bagi Bank Umum Syariah serta poin-poin apa saja yang harus ada dalam pelaksanaan Good Corporate Governance mengakibatkan GCG bank hampir serupa satu sama lain. Jika GCG bank serupa satu sama lain dampaknya tidak terlalu besar pada persepsi masyarakat karena GCG bank umum syariah satu dan lainnya hampir sama. Hasilnya indeks Good Corporate Governance tidak berpengaruh signifikan terhadap jumlah dana pihak ketiga.

\section{Pengaruh Indeks Islamic Social Reporting terhadap Jumlah Dana Pihak Ketiga Pengaruh}

Pengaruh Indeks ISR terhadap jumlah dana pihak ketiga secara parsial dapat dilihat dari hasil tingkat probabilitas (†statistic). Berdasarkan hasil pengolahan data diketahui bahwa tingkat probabilitas (t-statistic) sebesar 0.0159 yang lebih kecil dari a (0.05), sehingga H_02 ditolak dan dapat disimpulkan bahwa Indeks ISR berpengaruh signifikan terhadap jumlah dana pihak ketiga.

Bank syariah yang menerapkan fungsi sosial akan membentuk kesan yang baik, mempunyai nilai lebih, mempunyai prestise yang tinggi daripada usaha yang hanya berorientasi pada keuntungan (profit) semata dimata nasabah (stakeholder) bank syariah karena keterlibatan perusahaan dalam kegiatankegiatan sosial berguna bagi kepentingan masyarakat luas. Aktivitas sosial dapat berupa pembangunan rumah ibadah, membangun prasarana dan fasilitas sosial masyarakat, menjaga lingkungan, pemberian santunan dan beasiswa, serta menerima dana zakat, infaq, sedekah, dan menyalurkannya kepada pengelola zakat.

jika bank syariah beraktivitas dan beroperasi dengan dengan kegiatankegiatan yang baik maka nasabah dan stakeholder akan merasa nyaman dan mendapatkan kesan yang baik pula yang 
Ruhana, et al/Jurnal Ekonomi Syariah Teori dan Terapan Vol. 5 No. 4 April 2018: 264-278; PENGARUH TANGGUNGJAWAB PELAKSANAAN FUNGSI BISNIS DAN FUNGSI SOSIAL TERHADAP JUMLAH DANA PIHAK KETIGA BANK UMUM SYARIAH DI INDONESIA (PERIODE TAHUN 20102015)

kemudian akhirnya citra bank syariah menjadi positif. Sebaliknya jika bank syariah beraktivitas dan peroperasi secara dzalim melakukan kegiatan maysir, gharar dan lainnya maka nasabah dan stakeholder mendapatkan kesan yang buruk yang kemudian akhirnya citra bank syariah menjadi negatif. Keraf (1998: 132) menyebutkan bahwa keuntungan jangka panjang dari tanggung jawab dan keterlibatan sosial adalah terciptanya suatu citra positif dimata masyarakat. Citra positif akan membentuk kepercayaan yang sangat menguntungkan bagi perusahaan

Wibisino (2007: 84-87) menyebutkan bahwa salah satu manfaat dari penerapan aktivitas sosial perusahaan adalah memperbaiki hubungan dengan stakeholders, sehingga dapat menimbulkan trust (kepercayaan) pada perusahaan. Manfaat lain dari penerapan aktivitas sosial adalah dapat menjadi tiket bagi perusahaan menuju peluang pasar yang terbuka lebar, termasuk di dalamnya akan memupuk loyalitas konsumen dan mendapatkan pangsa pasar yang besar. Peluang mendapatkan penghargaan juga semakin besar bagi perusahaan yang melakukan aktivitas sosial. Penghargaan yang didapat akan semakin meninggikan nilai perusahaan yang kemudian akan menungkatkan kepercayaan stakeholders kepada perusahaan termasuk masyarakat yang kemudian akan menaruh dananya pada bank umum syariah. Dana pihak ketiga merupakan dana nasabah dalam bentuk simpanan. Simpanan menurut Undangundang No.10/1998 pasal 1 ayat 5 adalah dana yang dipercayakan oleh masyarakat kepada bank berdasarkan perjanjian penyimpanan dana dalam bentuk giro, deposito, sertifikat deposito, tabungan dan atau bentuk lainnya yang dipersamakan dengan itu.

Hasil dalam penelitian ini juga menunjukkan bahwa indeks ISR berpengaruh signifikan positif terhadap jumlah dana pihak ketiga yang ditandai oleh nilai koefisien indeks ISR yang bertanda positif. Pengaruh signifikan positif tersebut memberikan arti bahwa semakin baik bank umum syariah dalam melaksanakan fungsi sosial yang ditandai dengan nilai indeks ISR semakin tinggi maka akan menambah jumlah dana pihak ketiga pada bank umum syariah.

\section{Pengaruh Indeks Good Corporate} Governance dan Islamic Social Reporting terhadap Jumlah Dana Pihak Ketiga Secara Simultan

Hasil penelitian ini menunjukkan bahwa indeks GCG dan ISR secara simultan berpengaruh signifikan terhadap jumlah DPK. Pengaruh indeks GCG dan ISR terhadap jumlah DPK secara simultan dilihat dari tingkat probabilitas (F-statistic) sebesar 0.000000 yang lebih kecil dari a (0.05), sehingga H_03 ditolak dan dapat 
Ruhana, et al/Jurnal Ekonomi Syariah Teori dan Terapan Vol. 5 No. 4 April 2018: 264-278; PENGARUH TANGGUNGJAWAB PELAKSANAAN FUNGSI BISNIS DAN FUNGSI SOSIAL TERHADAP JUMLAH DANA PIHAK KETIGA BANK UMUM SYARIAH DI INDONESIA (PERIODE TAHUN 20102015)

disimpulkan bahwa indeks GCG dan ISR secara simultan (bersama-sama) berpengaruh signifikan terhadap jumlah dana pihak ketiga bank umum syariah di Indonesia tahun 2010-2015. Dengan Adjusted R2 sebesar 0.688344 yang berarti variabel independen mampu menjelaskan variabel dependen sebesar $68,83 \%$ sedangkan sisanya dijelaskan variabel lain diluar model.

Hasil signifikan variabel independen dalam mempengaruhi variabel dependen menunjukkan bahwa variabel independen dalam penelitian ini dapat dijadikan sebagai bahan pertimbangan atau strategi dalam meningkatkan jumlah dana pihak ketiga pada bank umum syariah di Indonesia. Variabel juga bisa digunakan sebagai prediksi perilaku nasabah yaitu nasabah yang memiliki kepercayaan tinggi terhadap bank umum syariah yang mau bekerjasama dan bertransaksi dengan bank, begitu juga sebaliknya. Sehingga menjaga nilai kepercayaan merupakan amanah dari nasabah yang harus dijaga.

\section{SIMPULAN}

Berdasarkan analisis data dan pembahasan yang dilakukan pada bab sebelumnya, maka kesimpulan dalam penelitian ini adalah sebagi berikut:

1. Indeks Good Corporate Governance secara parsial tidak berpengaruh signifikan terhadap jumlah dana pihak ketiga pada bank umum syariah di Indonesia tahun 2010-2015.

2. Indeks Islamic social reporting secara parsial berpengaruh signifikan positif terhadap jumlah dana pihak ketiga pada bank umum syariah di Indonesia tahun 2010-2015.

3. Indeks Good Corporate Governance dan Indeks Islamic social reporting secara simultan berpengaruh signifikan terhadap jumlah dana pihak ketiga pada bank umum syariak di Indonesia tahun 2010-2015.

\section{DAFTAR PUSTAKA}

Al-Qur'an dan Terjemahannya.

Ajija, Sochrul D, Dyah W.Sari, Rahmat H.Setianto, dan Martha R. Primanti. 2011. Cara Cerdas Menguasai Eviews. Jakarta. Salemba Empat.

Al Qurthubi, Syaikh Imam. 2009. Tafsir Al Qurthubi. Jakarta: Pustaka Azzam

Anshori, Muslich \& Sri Iswati. 2009. Buku Ajar Metodologi Penelitian Kuantitatif. Surabaya: Airlangga University Press

Antonio, Muhammad Syafi'i. 2001. Bank Syari'ah Dari Teori Ke Praktek, Jakarta: Gema Insani.

Boone, Louis E. \& David L. Kurtz. 2002. Pengantar Bisnis Jilid 1. Jakarta: Erlangga

Brigham, Eugene F. \& Joel F. Houston. . Manajemen Keuangan. Jilid 1. Edisi 
Ruhana, et al/Jurnal Ekonomi Syariah Teori dan Terapan Vol. 5 No. 4 April 2018: 264-278; PENGARUH TANGGUNGJAWAB PELAKSANAAN FUNGSI BISNIS DAN FUNGSI SOSIAL TERHADAP JUMLAH DANA PIHAK KETIGA BANK UMUM SYARIAH DI INDONESIA (PERIODE TAHUN 20102015)

8. Terjemahan oleh Dodo Suharto dan Herman Wibowo. 2001. Jakarta: Erlangga.

Dendawijaya, Lukman. 2003. Manajemen perbankan. Ghalia Indonesia

Departemen Agama Rl. 2011. Al-Qur'an Tajwid \& Terjemah. Bandung: CV Penerbit Diponegoro

Emirzon, Joni. 2006. Regulatory Driven dalam Implementasi Prinsip-prinsip Good Corporate Governance pada Perusahaan di Indonesia. Jurnal Manajemen dan Bisnis Sriwijaya Vol.4 No.8 Desember. Palembang

Gujarati, Demodar N dan Dwan C. Porter. 2013. Dasar-Dasar Ekonometrika. Edisi 5 Buku 2. Jakarta: Salemba Empat

Gumanti, Tatang A. 2009. Teori Sinyal dalam Manajemeng Keuangan. Majalah Usahawan Lembaga Management FEUI No.06 TH XXXVIII.

Haniffa, Ros. 2002. Social Reporting Disclosure: An Islamic Perspective. Indonesian Management \& Accounting Research Vol 1, No 2 pp 128-146.

Indriantoro, Nur \& Bambang Supomo. 2011. Metodologi Penelitian Bisnis Untuk Akuntansi dan Manajemen. Edisi 1. Yogyakarta: BPFE

Ismail. 2011. Perbankan Syariah. Jakarta: Kencana.

Jensen, Michael C. \& William H. Meckling. 1976. Theory of The Firm: Managerial

\begin{abstract}
Behaviour, Agency Cost and Ownership Structure. Journal of Financial Economics 3, (Online), (http://www.sciencedirect.com/scie nce/article/pii/0304405X7690026X, diakses 11 Mei 2016). 305-360.
\end{abstract}

Kasmir. 2006. Manajemen perbankan. Jakarta: Raja Grafindo Persada

Katsir, Ibnu. 2005. Tafsir Ibnu Katsir. Jilid 8. Bogor. Pustaka Imam Syafi'i.

Keraf, Sonny. 1998. Etika Bisnis Tuntutan dan Relevansinya, Yogyakarta: Kanisius

KNKG. 2006. Pedoman Umum Good Corporate Governance Indonesia. Jakarta: Komite Nasional Kebijakan Governance

Mahaputra, Adindha. 2011. Mekanisme Tata Kelola Perusahaan yang Baik dan Luas Pengungkapan Pelaporan Tanggung Jawab Sosial pada Perusahaan yang Masuk Corporate Governance Perception Index. Skripsi Universitas Airlangga

Nurhayati, Sri dan Wasilah. 2009. Akuntansi Syariah di Indonesia. Jakarta: Salemba empat

Othman, et al. 2009. Determinants of Islamic Social Reporting Among Top Shariah-Approved Companies in Bursa Malaysia. Research Journal of International Studies - Issue 12 (October, 2009)

Othman, Rohana dan Azlan Md Thani. 2010. Islamic Social Reporting of 
Ruhana, et al/Jurnal Ekonomi Syariah Teori dan Terapan Vol. 5 No. 4 April 2018: 264-278;

PENGARUH TANGGUNGJAWAB PELAKSANAAN FUNGSI BISNIS DAN FUNGSI SOSIAL TERHADAP JUMLAH DANA PIHAK KETIGA BANK UMUM SYARIAH DI INDONESIA (PERIODE TAHUN 20102015)

Listed Companies in Malaysia. International Business \& Economics Research Journal - April 2010.

Volume 9, Number 4

Peraturan Bank Indonesia Nomor 11/ 33/

$\mathrm{PBI} / 2009$ Tentang Pelaksanaan Good Corporate Governance bagi Bank Umum Syariah dan Unit Usaha Syariah

Peraturan Otoritas Jasa Keuangan No. 8/POJK.03/2014 tentang Penilaian Tingkat Kesehatan Bank Umum Syariah dan Unit Usaha Syariah

Sebagai Variabel Intervening. Jurnal Ekonomi Kuantitatif Terapan Vol. 7 No. 1 ISSN: 2301-8968.

Rivai, Veithzal. 2010. Islamic Banking: Sistem Bank Islam Bukan Hanya Solusi Menghadapi Krisis Namun Solusi Dalam Menghadapi Berbagai Persoalan Perbankan \& Ekonomi Global: Sebuah Teori, Konsep, dan Aplikasi. Jakarta: Bumi Aksara.

Sulistyanto, H.Sri. 2003. Good Corporate Governance: Bisakah Meningkatkan Kepercayaan Masyarakat?. Jurnal Ekonomi dan Bisnis -EKOBIS, Vol.4/No.1/Januari 2003. Fakultas Ekonomi Universitas Islam Sultan Agung Semarang.

Sulistyanto, H.Sri. 2008. Manajemen Laba Teori dan Model Empiris. Jakarta: Grasindo

Surat Edaran Bank Indonesia No. 12/13/DPbS

Surat Edaran Otoritas Jasa Keuangan No. 10/SEOJK.03/2014

Sutedi, Adrian. 2011. Good Corporate Governance. Jakarta: Sinar Grafika

Undang-Undang Republik Indonesia Nomor 10 tahun 1998 tentang perbankan

Undang-Undang Republik Indonesia Nomor 21 tahun 2008 tentang perbankan syariah
Wibisono, Yusuf. 2007. Membedah Konsep

\& Aplikasi CSR. Gresik: Fascho Publishing 